\title{
Must Biography Be Educational?
}

\author{
William Bruneau \\ University of British Columbia
}

\begin{abstract}
Michael Bliss. William Osler: A Life in Medicine. Toronto: University of Toronto Press, 1999. Pp. xiv +581.

Roland Hill. Lord Acton. New Haven and London: Yale University

Press, 2000. Pp. xxvi + 548.
\end{abstract}

A hoary but persistent tradition has it that people's lives, once in print, become exemplary and educational. Aristotle put his stamp on this idea, Plutarch famously supplied it with content, and, closer to our own time, the Victorians and the Edwardians gave it a moralistic twist. One thinks of Thomas Carlyle and his imitators, Leslie Stephen and his "moral progeny," John Morley and his imitators in the field of political biography, and Lytton Strachey, inimitable in his insight that "great" people mostly have feet of clay. In this lineage, the biographer's task (apart from recounting the agreed facts of a life) is to warn readers of moral danger, to urge moral greatness, or to tell of the links between greatness of character and greatness of deeds-or all three. In raising questions like these, and furthermore intensifying our sensibility, biographers were and are "educating" -but only if one accepts a morally-freighted definition of education.'

Since at least the 1920s biographers have been voting with their pens and their computers. Their verdict is in. They have moved away from moralized consideration of lives past and present. Under the old job description, biographers found themselves performing functions once restricted to prophets. Fewer and fewer found they could honestly make strong ethical, aesthetic, social, and political prescriptions, or see this as their primary obligation. The New York Review

'Aristotle, Rhetoric, 1360 a 18-37; Politics, ed. E. Barker, II c. V, $\$ 16$. Aristotle thought study of past lives, and of history more generally, would encourage an inductive habit of mind. Historical biography was necessary if one hoped to make political generalizations, especially about the "kinds of people" which this or that constitutional arrangement might suit.

Plutarch, Lives; Moralia (Cambridge, Mass.: Harvard University Press, various years). See also Donald A. Russell, Plutarch (London: Duckworth, 1973), and the same author's edited volume, Plutarch: Select Essays and Dialogues (Oxford: Oxford University Press/World's Classics, 1993). Further, P.G. Bietenholz, History and Biograpby in the Work of Erasmus of Rotterdam (Genève: Librairie Droz, 1966).

For an unpersuasive but colourful discussion of biographical moralism, see the oft-quoted H. Nicolson, Development of English Biography (London: Leonard and Virginia Woolf, later Hogarth Press, 1927). 
of Books and its London cousin show that this older form of life-writing still finds publishers. ${ }^{2}$ But it is fair to say a "new" historical biography is busting out all over.

The new biographer's tone veers only occasionally toward admonition, less often still to the giving of advice. These are no longer the biographer's tasks. The new biography claims to be neither monocular nor monolithic, permitting and inviting any number of ways to write or to argue about past lives, even in the pages of a single book, and even when the inferences and conclusions in various parts of a single book are inconsistent. ${ }^{3}$ Single-minded moralizing, singular narrative, and one-eyed accounts of personality-all are gone. ${ }^{4} \mathrm{It}$ is for the reader to supply the moral tone, and at least some of the inferences, and even to find unifying themes not visible on the biographical surface. (This gives the reader greater power, one might say - or a lot more work to do.)

Earlier schools of historical biography imposed "unity" on the object of study through a single writerly point-of-view. A biographer displayed the "singular" personality of the subject simply by describing the habitual practices, the typical dispositions, the usual response to changing circumstances, and the most repetitively expressed emotions, of the subject/object. After the advent of Freudian psychology, biographers sometimes, however amateurishly, tackled the question of motives. ${ }^{5} \mathrm{~A}$ biographer was expected (not merely allowed) to select evidence and data showing how the biographical subject made his or her way through life on the force of his or her "personality." The unity of argument that came with an emphasis on character and personality had rhetorical advantages particularly suited to the moralized biography.

Released from these narrow duties, the new biographer must take account of all the evidence. Thus Maynard Solomon's study of Mozart, driven by a Freudian account of personality, only just qualifies as biography, let alone "new

${ }^{2} \mathrm{~A}$ regular and thorough survey of reviews of biographical works will be found in "Reviewed Elsewhere," offered each quarter in Biography (Honolulu: Center for Biographical Research and University of Hawai 'i, 1977-present). For an example of modernist-moralist biography, see Lionel Gossman, Basel in the Age of Burckhardt: A Study in Unreasonable Ideas (Chicago: University of Chicago Press, 2000), esp. Gossman on Johann Jacob Bachofen, 109-200, and on Jacob Burckhardt, 201-410.

${ }^{3}$ See, for example, Jo Burr Margadant, ed., The New Biography: Performing Femininity in Nineteenth-Century France (Los Angeles: University of California Press, 2000.

${ }^{4} R$. Josselsen and A. Lieblich, eds., Making Meaning of Narratives (Thousand Oaks, California: Sage, 1999), passim.

'For a sharp, if out-dated criticism of this biographical form, see Jacques Barzun, Clio and the Doctors (Chicago: University of Chicago Press, 1974). Cf. the balanced and constructive assessment in Sol Cohen, Challenging Orthodaxies: Toward a New Cultural History of Education (New York: Peter Lang, 1999), Ch. 7, "In the Name of the Prevention of Neurosis: Psychoanalysis and Education in Europe, 1905-1938, 157-84.

'Dee Garrison, “Two Roads Taken: Writing the Biography of Mary Heaton Vorse," in S. Alpern etal., eds., The Challenge of Feminist Biography: Writing the Lives of Modem American Women (Urbana, Illinois: University of Illinois Press, 1992), 65-78, but esp. 67-8 on Freudian biographical method, notions of personality, and the new biography. 
biography" or history, however well-informed the writing and research.' Jan Swafford's study of Johannes Brahms, on the other hand, replete with detailed evidence on its subject's relations with landlords, barkeepers, publishers, neighbours, relatives, whole social classes, and a bewildering range of cultural forces -yet still interested in the underlying problem of Brahms's driving masculinity-is certainly "new biography."

Disparate forms of evidence, multiple narratives, thematic variety, and a jostling crowd of barely consistent explanations typify the new historical biography. To them we should add a characteristic and persistent appeal to context: the surrounding circumstances/structures of social class, public and private taste/preference (in everything from art to sex), social practices (including those that embody gender and/or sex), and politics (understood as any device we might use to negotiate differences among and between us). ${ }^{9}$

There is little so far to distinguish biography from the ordinary social history. Historians use "themes" to organize their evidence and to make sustained inferences and arguments, and they like to make narratives whose energy and colour move the reader to continue turning pages. On second thought, there is a difference: when I wrote "multiple narratives, thematic variety," I wanted to show that biographers choose narratives that make a story of the lives they are writing, but may introduce secondary themes having little to do with that story. A book's story-telling narratives may be accompanied by no explanatory themes at all. Musical biography is notorious for this very thing, as for instance the relentlessly factual, chronologically-bounded narratives in Mary Jane PhillipsMatz's flat biography of Giuseppe Verdi, and Léonie Rosenstiel's double narrative of the life and (wholly separate) work of Lili Boulanger. ${ }^{10}$ Historians must give greatest weight to theme and inference, or at any rate, give narrative and theme equal weights.

This means social historians can write biography, and can sound and look like "new biographers" as they turn out their articles and books. But at the final accounting, they must argue a connection between their subjects and their subjects' circumstances and contexts. The argument for subject/context connection, or subject/circumstance connection, is everywhere in Bliss's work on Osler, if a little less so in Hill's on Acton.

In the narrative/theme distinction lies a great difference between biography and all social history. The full force of the distinction is easiest to appreciate in one especially important application of biographical and social-historical theory -the history of education.

'Maynard Solomon, Mozart (New York: HarperCollins, 1995).

Jan Swafford, Jobannes Brabms: A Biograpby (New York: Knopf, 1997).

${ }^{9}$ For an extended discussion, see W.A. Bruneau, "An Apologia for Biography in French History," Proceedings of the Western Society for French History, 8 (1981): 568-76.

${ }^{10}$ Mary Jane Phillips-Matz, Verdi: A Biography (New York: Oxford University Press, 1993); Léonie Rosenstiel, Lili Boulanger: Leben und Werk, trans. and ed. Sabine Gabriel and Rolf Wolle (Bremen: Zeichen und Spuren, 1995). 
I suggest the new biography is about education, in at least three senses. Michael Bliss's study of William Osler and Roland Hill's book on Lord Acton illustrate all three in various degrees and ways. I doubt either author planned to write a book in the tradition of new biography. It is a mark of the times that both works display features of the new form, and not a few elements typical of work in the history of education.

In what senses is recent biography "educational"?

First, new historical biography is "educational" by definition if we take education to be any activity that opens participants' minds to multiple explanations for things, and invites temporary suspension of practical and moral judgment-at least long enough to consider those explanations equably. (Education may be many more things than that, but let this stipulative definition stand.)

New biographers are, in this general sense, educators. They do their best to listen to the multiple narratives that "life writing" permits, and invite their readers to do likewise. " Each narrative line entails a selection of evidence, and displays education at work in the life of the subject.

To historians of education, this must sound familiar. Over the past quartercentury, the field has splintered, no longer fixated on the rise of public education, its institutions or its content or its practices. ${ }^{12}$ Its practitioners have written increasingly often from the perspectives of the "weak and the silent," people on the cultural and educational margins, people in the mass rather than in elites. For a short while, some practitioners of educational history went so far as to say that education was built into culture-that it was going on whenever people acquired habits and worldviews, by whatever means. ${ }^{13}$ This was to treat education as mere socialization. Among the best known proponents of educational history in this vein was Lawrence Cremin, particularly in his revealing treatment of colonial American schooling and socialization. ${ }^{14}$

Since they try to see how multiple forces shape their subject(s), new biographers must come close to writing history of education. They ask how their subjects in turn "shape" the forces that are trying to "shape" them. ${ }^{15}$ They examine the interplay of social structures, social practices, and their subjects' emotional states as they experiences those structures and practices.

${ }^{11}$ Leon Edel, Writing Lives: Principia Biographica (New York: Norton, 1984), Part I, "The New Biography," 19-214, and esp. "Narratives," 173-214.

${ }^{12}$ Sol Cohen, Challenging Orthodoxies: Toward a New Cultural History of Education (New York: Peter Lang, 1999), esp. Chs. 4-5, 105-53.

${ }^{13}$ Bernard Bailyn, Education in the Forming of American Society: Needs and Opportunities for Study (New York: Vintage, 1960), passim.

${ }^{14}$ Lawrence Cremin, American Education: The Colonial Experience (New York: Harper and Row, 1970), esp. the important seventeenth chapter on "Configurations, ${ }^{\text {" 517-43. }}$

${ }^{15} \mathrm{On}$ interactions between biographers and their subjects, see Carolyn G. Heilbrun, Writing a Woman's Life (New York: Ballantine, 1988), 50-52; also, Lois Rudnick, "The MaleIdentified Woman and Other Anxieties: the Life of Mabel Dodge Luhan," in S. Alpern, et al., eds., Challenge, 118-21. 
The idea is partly to display great masses of fact, and to let them suggest plausible narratives of education. Take Swafford on Brahms. The power imbalances in the composer's early life, his poverty-stricken beginnings in $19^{\text {th }}$ century Hamburg, and the consequences-having to play for money in bars, and learning about sex and gender by seeing how women made their living in those bars-these things shaped Brahms, just as be later (in his relations with Clara Schumann) shaped them.

In brief, this kind of biography is about socialization. If we define education as little more or less than socialization, then new biography and history of education almost completely overlap. The trouble then is that almost anything will do. The relation between history and biography easily becomes tenuous and uninteresting. Educational history becomes indistinguishable from biography, and both shade into fiction, anthropology, ethnography, or even informed journalism. It was this that doomed Cremin's three-volume history of American education to remainder bins across dusty shelves. ${ }^{16}$ It is hard to make incisive explanations when writing about everything under the sun, all at one time. ${ }^{17}$

Through the 1980s and 1990s educational historians came to downplay or even to reject Cremin's example, however much they had learned from his failed revision of the field. Some late-20th century practitioners became expert in applying the methods and outlooks of cultural history, critical theory, and the linguistic turn. ${ }^{18}$ These writers worked on questions of gender, embodiment, social practice, and power relations as and when those relations became visible in teachers' and learners' working lives. Meanwhile, a great many other practitioners, worried and bewildered by the diversity of the new cultural history of education, turned to research and writing reminiscent of an older history of educationunderstood as the study of institutions and public educational politics. The field became multifarious, specialized, and ever more insistent on proper balance between facts and strong arguments. Thus practitioners of education-history specialities find it hard to cross boundaries, and to attempt anything resembling a full-blown synthesis.

New biography permits and invites an educational interpretation or understanding. But history of education, as field or sub-discipline, will not and ought not to assimilate the multiple themes characteristic of new biography. Practitioners are having enough trouble seeing how to bridge the divides that separate forms of argument in educational history, let alone inviting and ingesting the questions and insights of biography. The best we can hope for is a vague cross273-99.

16S. Cohen, "Lawrence A. Cremin: Lives and Transformations," in Cohen, Challenging,

${ }^{17}$ For a powerful discussion of the tension between explanation and narrative, theme and description, see Lionel Gossman, Basel in the Age of Burckbardt, op. cit., ch. 12, " Not Narrative, but Historical': The Cultural History of Greece," 297-346. This section compares and contrasts Jacob Burckhardt's Griechische Kulturgeschichte with the Kultur der Renaissance in Italien.

${ }^{18} \mathrm{~J}$. D. Wilson, "The New Diversity in Canadian Educational History," Acadiensis 19, 2 (Spring 1990): 148-69; Cohen, Challenging, passim. 
fertilization, awaiting a time when biography is prepared to accept the argumentative and logical requirements of history and history of education-and when history of education is ready to move on to a new synthesis. I'm reminded of the wary sisterhood of classical music and "gangsta rap." Both are music, but there is little exchange between the two, and precious little serious borrowing between scholars researching either. It is high time we all moved on to try an exchange or two- understanding that like social historians generally, historians write lives must finally give precedential force to theme and argument.

Some practitioners of biography still write monothematic books, and few think even for a moment of adopting a multiple-narrative scheme. These "old" biographers do useful work, but in neglecting the inferential possibilities of the "new" they may be failing an important intellectual test. The biographical tribe is, like the educational history tribe, a divided house, and much intra-disciplinary, in-house talk and discussion is needed before biographers reach out to educational history. But if inter-tribal discussion is difficult and uncertain, it is every historian's and every biographer's duty to attempt it. Their several jobs are at some points so similar, that it is intellectually necessary to reach across the disciplinary divide, and to learn what one can.

Historically-minded readers apply to any new biography a series of tests. Does it consider the multiple arguments and optics open to it? Does it pay attention to education in our first, broad sense? If not, why not? Further, does it work in a systematic way to detect the manifold effects of social and cultural context, or circumstance, on the subject/object of research? Does it make a sustained argument for subject-context connection? The older forms of biographical argument, well done, can withstand all of these questions. My point is that those questions should be put, and that Bliss and Hill should expect them.

$$
x * x
$$

Now to my promised second and third definitions of education. In both it is easier to see links between biography and history. Able biographers ought to consider all three definitions - but maybe the last two most of all-whether or not they are professional historians, and whether or not the biographees were professionals in education.

The second definition covers all cases where communities are at work to see that individuals learn a profession or a vocation or a trade, acquire a nationality, or accept an ideology or a set of values. These may happen in apprenticeships, in mentoring, in public "information" campaigns undertaken by the State, in non-formal settings at all ages, or in schools, universities, and other formal educational institutions. In every case, the intention to educate/inculcate/train is explicit, and leaves behind evidence and clues. No biographical subject could get through life without experiencing this sort of education, and without considering it, no biographer could hope to produce a believable life-story or lifeaccount. 
This second definition is sufficiently narrow, and widely enough agreed on in the writing community, to produce a large and generally strong body of articles and books. This body of work has given the humanities and social sciences-but social and cultural history more than most-a set of specialized norms. It has its own premises, research methods, and forms of argument. It is a field of experts and expertise. None of this means the non-historian or nonspecialist is excluded; rather, it means that a biographer who chooses not to explore it loses in argument and expository power. By this standard or definition, the biographers of Osler and Acton are in some slight difficulty.

Before turning to the detail of these two books, I offer a third definition of education, and of educational history, perhaps the most familiar of all. This is education as institution, as visible curriculum (as opposed to hidden curriculum), as pedagogy, as carrot-and-stick or currency in the competitive business of life. It is just possible that a person somewhere in the world could live a whole life without much experience of these things, but the absence of them would itself be significant. It matters that by this definition certain followers of the Buddha in some cases rejected education, and others did not. By the same token, the putatively anti-intellectual rejection of schooling in the works of Ivan Illich and his friends, and in Paul Goodman and his followers, has its own significance.

It is just possible to argue that biographers must always deal with education in this third sense, and could therefore profit by understandings in the history of formal education. But harried biographers cannot be expected to be expert in every (narrow) field on which they might draw. Short of full-blown expertise, there are many degrees of acquaintance with the field. It is fair to expect, let us agree, that life-writing replete with references to formal education should include more than just one historical perspective on formal education.

For Osler and Acton, whose lives were lived on different continents, formal education naturally had peculiar functions and meanings. Osler spent the greater part of his professional life in formal educational settings, at McGill, Johns Hopkins, and Oxford, not to mention student days in Ontario, Berlin, Vienna, Paris, and London.

Acton had an education mainly in sense 2, in an aristocratic European family based in Britain during the $19^{\text {th }}$ century, but Continental in roots and outlook. His involvement in formal education, sense 3 , was nonetheless extended and sustained. He spent eight years as a boy at Oscott, a well-reputed English Catholic boarding school. His ties and commitment to institutional education led him finally and famously to the Regius Professorship of History at Cambridge University. His long years as pupil-apprentice of Ignaz von Döllinger took him to lectures at the University of Munich. He never took a degree, in Germany or in England. Instead he maintained his faithful apprenticeship to Döllinger, in a decades-long succession of visits to diplomatic archives across western Europe. The two worked hard together in the greatest fight of their lives, the losing battle to persuade Vatican Council I in 1870 to reject the Doctrine of Papal Infallibility. 
Many narratives may be imposed on the evidence of Acton's life, and all invite educational argument. The narrative argument might come from family history. A further argument might be from cultural and diplomatic history in a Europe divided by nationality but united by cultural and imperial pretension. Yet another argument-narrative arises from the ways organized religious life and private religious practice account for Acton's choices. In Osler's case, although his institutional affiliations were from the beginning far more sustained than Acton's, the same narrative choices arise: familial, cultural, and religious. In the lives of both men, education in the formal and visible sense permits competing explanations, and invites divergent narratives based on distinct selections of evidence, and on differing inferences about the subjects' motives and intent.

Whether we see education as apprenticeship, or as an activity framed by formality and intent, it would be hard to understand these two men without some use of the methods and ideas of educational history. Similarly, narrative threads in the evidence from both lives suggest inferences and multiple stories of a kind familiar in new biography.

If (and this is a big "if") biographers Bliss and Hill concern themselves in a systematic way with the problem of education, how far do they go toward taking up the challenges of the new biography? And in writing biography, do they essay a form of educational history?

John Emerich Edward Dalberg Acton (1834-1902), First Lord Acton, was born in Naples to Maria Louisa Pelline von Dalberg and to Sir Ferdinand Richard Acton. Ferdinand was the son, and the future Lord Acton the grandson, of an Englishman who in the 1790 s and early 1800 s was Prime Minister of the Kingdom of the Two Sicilies. The Actons were

Shropshire baronets-conservative, loyalist supporters of the monarchy and the Church of England....In the eighteenth century something of a jolt occurred [when $t$ ] hree of its members, independently of each other, returned to the faith of their fathers [Catholicism]. (Hill, $\mathrm{xx}$ )

The connection between the English and the Neapolitan Actons, which takes thirty or so pages to explain in Hill's book, need not detain us. Suffice to say that in the tiny, highly interconnected world of $19^{\text {th }}$-century European aristocracy, the English-Italian connection was possible and barely noteworthy.

The Dalbergs, mean while, were a German aristocratic family more ancient still than the Actons. Fitted out with relations and homes in Bavaria, France, and Italy, the Dalberg clan usually spoke French and Italian at home, moved often from one pleasant European home to another, and despite the tribulations of the Napoleonic era, were comfortably well off at the time of the ActonDalberg marriage (Hill, 12-13).

Our future Lord Acton spent his childhood and adolescent winters in England, and his summers in France, Italy, and southern Germany. Although his family were cautious and moderately conservative, Acton's travels and 
learning made him increasingly cosmopolitan and liberal. He grew up multilingual, widely travelled, and conscious of the multiple meanings and narratives of his family history.

His childhood was shaped by the early loss of his natural father, and the acquisition of Lord Granville as stepfather. Granville eventually, and not especially tactfully, pushed Acton into a brief political career as a Liberal. Acton went (spring 1853) with the English delegation to the New York industrial exhibition, then (1856) to Russia as an attaché to Granville and a large British deputation for the coronation of Tsar Alexander II, and with Döllinger to Rome in 1857 (for political, scholarly, and religious reasons).

Acton was little inclined to play an active part in British politics. He had returned to England at age twenty-three from studies in Munich intending to teach English Catholics what he had learned in Germany about the Church and history. As the editor of learned Catholic journals of liberal outlook, he was bound to be bitterly disappointed by the thettolike mentality of English

Catholics, who were just emerging from centuries of oppression. (xxi)

He envisaged a career as publicist and educator. Hill writes (xxii) that "Acton was particularly interested in the political education of Catholics." Although Acton knew or came to know all the political greats of $19^{\text {th }}$-century England, Prime Minister Gladstone among them (87-90), he left the Commons as quickly as he decently could. ${ }^{19}$ For decades he edited learned reviews with tiny circulations, read by liberal-minded Catholics and Protestants alike (chiefly The Home and Foreign Review, The North British Review, and The Rambler), and more especially by those influential Anglicans who followed J.H. Newman to Rome.

Acton married (157-72) his cousin Maria Arco von Valley in 1865, and among their half-dozen children was Richard, the future heir and second Lord (we are at the fourth remove, by the way, in the Acton family, and the fifth Lord waits in the wings). The family depended in the $19^{\text {th }}$ century on agriculture for its income, and Lord Acton occasionally found it necessary to spend time with relatives and friends in Germany and France, or to live in the Riviera. It was a question of maintaining a gentle way of life, but also a convenience in a life given to liberal-Catholic causes. It was cheaper to live on the Riviera or in rural Germany than in England, and closer to the springs of international decision making.

In February 1895, Acton was appointed Regius Professor of Modern History at Cambridge. Prime Minister Rosebery wrote his predecessor Gladstone to say that Acton was his favoured candidate for Cambridge, the Oxford Regius Professorship having just gone to F.Y. Powell. But:

${ }^{19} \mathrm{Hill}$ (354-6) tells how Acton in the 1890s performed the service of reconciling Queen Victoria and Gladstone, each to the other's existence. Both were well along in years, but as stubborn in their suspicions of one another as ever. 
1. he is a Roman Catholic. 2. I do not feel sure from his writings that he would find it easy to impart his knowledge to others-to be in short a good lecturer.

3. I do not think that he was at Oxford or Cambridge. No. 1 is the crucial objection. Acton is eminently anti-papal, but Great Britain on these points is eminently suspicious. (Rosebery qu. in Hill, 366).

Gladstone in the end strongly supported Acton's appointment, as did old friends already teaching at Cambridge. The position provided Acton with needed income, stimulus for new writing, and a psychological boost.

For Acton was an unexpectedly good lecturer. Scholar-statesmen were then, as now, objects of curiosity. A young George M. Trevelyan went to his first lecture, and reported 200 auditors. Acton had by this time developed a theory of "scientific history" that attended closely to the importance of primary, archival sources and asserted the revelatory power of "atomic facts." This was a crucial time in the development of sociological studies and the social sciences generally. Hobhouse was teaching at Oxford, Durkheim at the Université de Bordeaux, and Small at Chicago, all three were busily constructing the new discipline, complete with journals, students, and large-scale research programmes. Whether or not it was his intention, Acton's ideas fit well with the ambitions of these rising schools of social inquiry. No wonder his lecture room and list of seminar students were perpetually full.

Acton was disinclined to recommend great changes in the curriculum or in the Cambridge lecture-tutorial system, but nevertheless made full use of formal structures to shape the ambitions and the historical powers of his students. In 1896, Acton had the opportunity to extend his influence across the entire educated world: he was to take

general direction of a monumental history of the world....Acton's faith in the new scientific history, as he had expanded on it in his Inaugural Lecture, had made an impression in Cambridge. (392)

The result was the Cambridge Modern History (vol. I, 1902-vol. XII, 1912). Acton was general editor for the series, but became too ill to write his contribution to the opening volume, and did not live to see its publication. He died, an oddly tragic figure, in September 1902.

Let it be said that Hill's work is lucid, well-argued, and persuasively set in the social, intellectual, and religious worlds Acton knew. This is fine biography by any standard. It is thus a reliable guide to a hundred years of European history, not just a map to Acton's life. Hill effortlessly provides that guide in the margins, as it were, of a sustained life-study. His book uses an enormous range of primary sources, in some cases for the first time, and surpasses Himmelfarb's account on that score. ${ }^{20}$

But is Hill a "new biographer"? Has he understood the educational forces tied up in the narrative strands he finds in Acton's life? Does he understand the educational meanings tied up in Acton's multiple apprenticeships? Finally, does

${ }^{20}$ Gertrude Himmelfarb, Lord Acton: $A$ Study in Conscience and Politics (Chicago: University of Chicago Press, 1952). 
he make any use of explanations that arise because of Acton's involvement in formal, recognizably educational activities - from school, to public education through print, to politics, to Cambridge at the end of Acton's life?

As in all big books on big subjects, there are problems. The Actonian controversies - on the meaning and possibility of intellectual history, on the meaning and power of atomic facts, on the roots of power in industrial societies, and on practical morality-are left in atate 1902. We hear nothing of Lewis Namier's view of Acton's research methods, Isaiah Berlin on Acton's intellectual history and its weaknesses, or Collingwood on Acton's inconsistent beliefs that history could be idea and factum all at one time. We have only stage hints to push us to further studies-for instance, to see how Acton's essays on nationality, liberty, religious diplomacy vs. state diplomacy, and the Irish question have been interpreted by politicians and scholars in the century since Acton's death. (Hill's excuse might be that these later debates followed Acton's death. But they didn't. They were well launched, some as early as the 1850 s. These important matters deserve more treatment, even at the expense of another fifty pages.)

As for narratives, Hill provides them by the chapter. On Acton's peculiarly cosmopolitan family and childhood, we have two chapters; on his apprenticeship to Döllinger, another; on travel to archives and religious meetings two chapters; on politics, two; on editing and writing, two and a bit; and so on. Yet these narrative themes are not written so as to confront one another, as they must have done in life. Hill mentions the tensions in Acton's life between writing and politicking, family life and public life, the country life and the urban life once or twice about the tension, but they immediately recede into the background, to be heard of a hundred pages later.

The book's organization is sensible, but it is not "new" biography. We miss the continual presence of disturbing, even contradictory threads, although Hill scrupulously provides evidence for those threads. The end result is a series of missed explanatory possibilities.

Take the question of money. We know the world agricultural economy decided a good proportion of Acton's annual "salary." But what proportion exactly? Where did his wealth (defined in monetarily and non-monetarily) come from? When he spent months with his German relatives, how much wealth (free rent, business considerations, and the like) changed hands? In what ways was Acton's family economy like to and different from that of his neighbours? Who were his neighbours? Was Acton better or worse off than they? Money was by no means the only measure of a family's wealth. Did the Actons have enough "history" to make up for any weakness in their real estate holdings?

Hill shows just enough of Acton's affairs to persuade us that finances were a persistent background theme, and could well provide a convenient narrative tension throughout the book. There are a dozen more such themes, at the very least, and Hill touches on them all-gender, class, the power of various ideologies, urban-rural differences, the daily life of the privileged classes (but not the excluded classes, on whom the Actons relied every day). Hill touches on 
these, but neither confronts them nor writes so as to make the themes confront one another. As a result, Hill misses an educational aspect of Acton's life.

Let's stick with money for a bit: Acton had a half-dozen or so children. Each had to learn the ways of the European gentry, and also about family finances. Did Acton teach them? Did the children learn from the family, taken as a whole? Even if nobody talked about this kind of thing - especially if nobody talked about it - it had to be learned one way or another. In the silences about money, almost as much as in the Actons' assertions about it, there are hints of the educational life of the whole family, and certainly of Acton's fiscal pedagogy.

There was a significant tension in Acton's life between his bibliomania and the warnings of his accountants. Acton constructed an entire wing to his Aldenham house for the 70,000 books of his library. Book-collecting across eastern and western Europe and storage of the spoils became a central part in his life. But how central? And why? Was book collecting itself an education? Given Acton's busy life, how much time could he spend with those 70,000 books? The cost to Acton of his bibliomania, in time, money, and energy, must have been very evident in the quarterly letters from his lawyers, estate managers, and accountants (Hill, 59-62), and at every moment when he had to make choices about how to spend his allotted hours and days. It is precisely these kinds of decisions that demonstrate a person's underlying value-systems and principles.

It would have been nice to know how far Acton's library showed traces of debates on the British Empire, on the question of State support for education, and like matters. We do know a great deal of Acton's views on Irish Home Rule, on the proper spheres of Church and State, on the dangers of religious establishment generally, and so on. But how revealing it would be to see the practical and empirical evidence of all this...in Acton's selection of reading matter. Yes, we have the hundreds of articles Acton wrote and edited on every one of these great questions, but what of the practical evidence to be found in his Aldenham book list? ?21

I cannot resist a parallel with the insights of students of the English Renaissance and Reformation periods, fortunate in having booklists of Oxford and Cambridge students, fellows, and booksellers from the $16^{\text {th }}$ century, and thus able to put to the test the canonical generalizations about university curricula and practice. ${ }^{22}$ One wonders whether Hill might have been led to these sorts of

${ }^{21}$ Through the good offices of people who knew both men, Andrew Carnegie purchased the Acton library in 1890, offering it afterward to Cambridge University Library, where it still is. A complete book list was prepared in the summer of 1890 .

${ }^{22}$ For examples of the use of booklists, see James K. McConica, English Humanists and Reformation Politics under Henry VIII and Edward VI (Oxford: Clarendon Press, 1965, corr. ed., 1968), 88-92, 161ff; Mark H. Curtis, Oxford and Cambridge in Transition, 1558-1642 (Oxford: Clarendon Press, 1959, corr. ed. 1965), 282-90; and W.A. Bruneau, "Humanism, the University, and Monastic Life: The Case of Robert Joseph, Monk of Evesham," British Joumal of Educational Studies 20 (1972): 282-301. 
questions had he adopted some of techniques of the new biography (and bibliography).

On the question of formal education, Hill has little to regret. His discussion of Acton's education at Oscott and later Munich and Cambridge (for as a teacher, Acton remained a learner) is fine. However, there is a "but." Accomplished practitioners of institutional/educational history could have offered several viable and helpful lines of inquiry and argument, had Hill read them. Their absence does not disable his book, but it is poorer without them. Two examples will suffice.

The new collectively written history of Oxford University rightly makes much of the educational work done by publishers, broadcasters, and journalists, many directly connected to the institution. ${ }^{23}$ The activities of the Extension Department in publication and broadcasting are part of the story, but far more is the work of the publishing arm, the Clarendon Press and the larger Oxford University Press. ${ }^{24}$ Students of institutional history of education nowadays do not neglect things like university or school presses. Acton was an instant beneficiary of the Cambridge University Press. How then did he see his work at the Press, especially in comparison and contrast with the rest of his professorial functions? What overlying or underlying educational theory drove the man? Hill does not get around to telling us. I think he knows, and that he may yet write about this. ${ }^{25}$

The remaining definition of educational history, the one concerning apprenticeship and mentoring, led to massive publication and research in the last century, and promises to do likewise in the new one. Some of that new work is done under the label of adult education, and some published as historical anthropology. The central questions have to do with the quasi-formal business of shaping and helping others to learn their professions, to become autonomous in their fields (anything from accountancy to politics), and to become mentors in their turn. ${ }^{26}$

There are no references to work from that branch of educational history in Lord Acton, but Hill asks questions typical of the field. Readers of Himmelfarb on Acton will recall her description of the estrangement between Döllinger and Acton, with its emphasis on intellectual differences that eventually ended the

\footnotetext{
${ }^{23}$ T.H. Aston, gen. ed., History of the University of Oxford (Oxford: Clarendon Press, 1984-), 8 vols., but see esp. vols. 6, pt. I, and 8 in its entirety.

${ }^{24} \mathrm{P}$. Sutcliffe, The Oxford University Press: An Informal History (Oxford: Clarendon Press, 1978); Michael H. Black, Cambridge University Press, 1584-1984 (Cambridge: Cambridge University Press, 1984).

${ }^{25}$ Professor Himmelfarb's book is unhelpful on matters of educational argument and theory in Acton's life and writings. Here is an attractive $\mathrm{PhD}$ thesis-in-waiting.

${ }^{26}$ On this general question, see Elizabeth Smyth, et al., eds., Challenging Professions: Historical and Contemporary Perspectives on Women's Professional Work (Toronto: University of Toronto Press, 1999), esp. introductory essay at 3-24.
} 
men's partnership. ${ }^{27}$ Hill offers (301-2, 308-9, 316-24) a multiple explanation, showing how far the two were connected by inclination, habit, and practice until Döllinger's death. Döllinger was by then excommunicant, and Acton by then in profound disagreement with his old teacher. Their differences never stopped their correspondence, filled with ideas and touched throughout by a sincere fellow-feeling. Hill is revealing on the many forms of educational work, teacher with pupil with teacher, that had kept the life-long Acton-Döllinger relation alive. Hill has written, without ever intending it, a fine study of apprenticeship and mentoring.

In choosing to write about William Osler (1849-1919), Michael Bliss faced the difficulty anyone writing the life of a "saint" must resolve, one way or another: getting past the hype. In Osler's case, the hagiographs were at work even before he died, and have remained busily at work ever since. Professor Bliss had to find some way of drawing this tiger's teeth, and denying the ready-made narrative that Oslerians and Oslerologists (yes, there are such persons) would have liked.

Bliss has been careful and "inclusive" in research, determined to keep in mind (and in balance) a host of arguments/narratives, even if some of them are mildly inconsistent. We have, for example, the argument that Osler was a strongminded academic medical man at Johns Hopkins, and the rather different case that he was naïve in battles between people, departments, and faculties. It is not especially clear whether Osler was simply taking the high road in academic disputes, or merely bored with academic politics. It might seem odd to claim he was all at one time a strong-minded academic and a weak-minded academic politician, yet these views are defensible and probably correct. In bringing them out Bliss draws a little from the new biography, but much more from the traditions of good social history: let the evidence decide the themes, and don't worry if there seem to be an alarmingly large number of themes.

It takes a good deal of skill to keep all these balls in the air. Bliss manages it, complete with a little self-deprecating humour. In his persuasive treatment, Osler emerges a likeable and hugely energetic figure. Making a virtue of necessity, Bliss writes an entire chapter ("Osler's Afterlife," 477-504) showing how Osler's colleagues came to be so worshipful. The workings of the medical publishing "industry," the networks of American, Canadian, and British physicians and their mutual dependencies, and the peculiar niche in medical history occupied by Osler's textbook-all these forces, along with the man's personality, help to explain the rise, fall, and rise of Oslerian worship.

Here the competing narratives are consistently present, and not just in their own chapters (as with Hill's Acton). Osler was born in a Canadian backwater to an English-born Anglican curate. "Willie" thus knew first-hand about

${ }^{27}$ Himmelfarb, Lord Acton: A Study, 146-50. 
rural and peasant life, its toughness and its rough democracy, its hard lessons on the fragility of people and power of Nature. Bliss continually draws us back to these narrative themes with persuasive examples, always maintaining an apparently effortless balance between description and analysis. Through his career as student at the Toronto Medical School and then at McGill's Faculty of Medicine (M.D., CM, 1872; see Bliss, 65-67), later as medical practitioner in Montréal and lecturer in Medicine at McGill, Osler's family background and well-rooted naturalism help to explain his enormous breadth of interest, and his diagnostic powers. Bliss succeeds as no one has until now in showing how the background is tied to the foreground-how Osler's private and personal history explain his practical and intellectual outlook, how subject is connected to context and circumstance.

Bliss succeeds where Hill does not. Acton was a mediocre politician, in the usual partisan and parliamentary senses of the term. The reason may well be his internationalized family life, and the relatively small number of hours and days he spent in Britain in many, if not most, years of his life. Acton was simply out of touch. There was besides Acton's psychological distance from the "ordinary" Irish and English constituents he was expected to represent, and his honest distaste for deal-making. These two themes, social and psychological, do not figure in any systematic way in Hill's biography. Bliss's book is fashioned so that the themes are strong from one end to the other.

Questions of nationality and tribalism arise in both Acton's and Osler's cases. Hill acknowledges these must have been "problems" in the life of his subject, but does not return to them in any powerfully explanatory way. We finish the Acton biography uncertain just how far, if at all, Acton's Englishness accounted for his failure in 1870 , his peculiar literary output, and his eventual distance from his old mentor. In the Osler biography we are not left with this kind of uncertainty. Osler's open-hearted interest in the miserable conditions of life in late $19^{\text {th }}$-century Montréal, his Canadian-ness, his pragmatic and antispecialist view of science, and his honest ambition to make enough money to be comfortable, persistented all through his adult life. Professor Bliss never loses sight of those themes, and nearly always asks the educational questions about Osler's ability to persuade his colleagues, his students, his patients, and, later, the public of his ideas and vision.

Osler spent months in England doing advanced medical study (68-75), then a winter (1873-4) in Berlin and Vienna (75-8). The power of the German academic profession, the pedagogies of the clinic and the classroom, and the organization of medical science and medical practice in Prussia and in Austria, had visible and lasting effects on Osler's outlook. Compare Acton's life of learning in Munich and chez Döllinger. On this comparison, Hill fares at least as well as Bliss.

Osler diverged sharply from Acton, of course, in the length of his teaching career. Osler had taught for decades before his appointment (1905-19) to the Regius Chair of Medicine at Oxford. It began with a relatively brief stint in Medicine at the University of Pennsylvania (1885-9), where he combined 
teaching and clinical practice, by now publishing a great deal in Canadian, American, and British journals. His next move was to the still-new Johns Hopkins University and hospital (1889-1905).

Osler's twenty years in the United States saw him married (1892) and, at almost the same moment, author of the most successful medical textbook of the day, The Principles and Practice of Medicine. Where Acton died historically intestate, as it were, Osler did not. After reading Bliss on Osler's way of learning his medicine through clinical practice and university teaching - how he passed on a taste for medicine to the young, how he combined authorship with political skill (especially in fund-raising for laboratories and hospital buildings) -after all this, we know why Osler was able to write his great book, in dozens of editions, and to continue publishing hundreds of articles and papers throughout.

Although the scholarly apparatus to Bliss's book includes few works on university history, he misses few themes favoured by writers in that field.. He deals directly, for instance, with matters of gender and race in his discussion of Osler's attitudes to admission, grading practice, and career planning (see 230-7):

The real 'others,' the stranger, in Osler's medical life were women. Osler had grown up in the what was effectively an all-male medical world....Every day [after the admission of women] men and women intereacted in classroom and clinic, and for many men this was not an easy adjustment. Like athletes suddenly finding female journalists in the locker room, they were uneasy, angry, petulant, and more than a little suspicious of the newcomers' motives. At the very least, as W.T. Councilman...said, they could no longer pee in the sink. (230)

Osler openly discouraged women from applying, but only until their applications were in. After that, he treated them with his trademark equanimitas. His attitude to the barely suppressed anti-Semitism of some colleagues was to disregard it, and draw Jewish students deeply into his teaching and his learning. It was as if Osler's pedagogy was so dominant a consideration that others faded.

The student begins with the patient, continues with the patient, and ends his studies with the patient, using books and lectures as tools, as means to an end. The student starts, in fact, as a practitioner, as an observer of disordered machines, with the structure and orderly functions of which he is perfectly familiar. Teach him how to observe, give him plenty of facts to observe, and the lessons will come out of the facts themselves. For the junior student in medicine and surgery it is a safe rule to have no teaching without a patient for a text, and the best teaching is that taught by the patient himself. [Osler's emphasis] (238)

Bliss was fortunate in having as a subject a person whose ability to write a clean sentence put to shame many an historian or literary figure of the day. Hill was no less fortunate in Acton. The difference is that in Bliss's Osler we see the shaping and re-shaping of medical pedagogy, ideas of curriculum, and medical practice, always driven by the same outlook that drove the pedagogy at Hopkins (238). In Hill's Acton, the pedagogy (in his case public education through publication) may have changed a good deal across Acton's adult life, but we cannot be sure, and certainly cannot guess at the reasons for change. 
These comparisons show that Professor Bliss did all three types of educational history, and did them well. I think his work is chiefly an educational biography, and belongs in that category, among others. It is arguably the equal of professorial biographies of Froude, Rutherford, Virchow, Eve Curie, Einstein (and especially the more controversial ones in this group-Rutherford, Curie, Einstein).

These two men exhibited still more commonalities:

-Osler had a happy family life (until the death in 1917 of his and Grace's only son in Belgium [Bliss, 438-42]), as did Acton, but for the early deaths of too many of his children);

-remarkably similar working habits and capacity for work (Hill and Bliss deserve much credit for paying attention to the daily working lives of scholars who marry intellectual demands with the bothersome pressures of administration, academic politics, and daily life);

-their determined bibliophilia and bibliomania;

-and finally, their deaths in office as Regius Professors, one at Oxford and the other at Cambridge, Acton in 1902 and (Osler in 1919).

These similarities are the stuff of narrative, more than of thematic explanation, but raise additional points to which an historian of education would want to attend.

It remains to ask of Bliss what he might have learned from a more systematic reading of work on the development of all the professions and disciplines in the $19^{\text {th }}$ and $20^{\text {th }}$ century universities. Would the works of Fritz Ringer, Konrad Jarausch, Roger Geiger, George Fox, and even Edward Shills, have helped him to see further and more sharply into his rich evidence?

Hill missed several opportunities. Reading about the controversies over curriculum, pedagogy, and public relations at Johns Hopkins, we could be forgiven for concluding that Osler was in the grip of friendships and animosities that decided the academic history of medicine in the university. But anyone who reads Fritz Ringer's (already outdated, but still valuable) Fields of Knowledge, or Mary Jo Nye on Science in the Provinces, or Axelrod on infighting in (Canadian) universities: any of these show that Osler's fights were surely about matters of academic territory, the certification of knowledge and the control of it, inside and outside the university, shifting boundaries and barriers between disciplines inside the university, and between practitioners and teachers of them... outside the academy altogether. If the fights were over power, certification, control, and territory, then personal differences have secondary and symbolic importance. I am not sure, to take this one further step, how best to interpret Osler's membership in the AMA (see Bliss, 149), or in any of the numerous and similar societies, some formal and national, some local and intimate (rather on the style of the Cambridge Apostles, come to think of it). Was the AMA membership and activity more than a way of asserting which group of doctors ought to make the New Order in American, or in British medicine? Or was it rather an outcome of earlier fights over the meaning of certification, the rise of specialisms and rewards for specialists, and so on. 
Here, Bliss would have profited from work in the professional field in which he was (if unwittingly) reading and writing-the history of higher education.

Let me add instantly that on the history of the medical profession, and on the evolution of medical science, basic and applied, Bliss is a clear and consistent guide. His sure touch and easy writing at times had me thinking I actually understood the elements of physiology and microbiology. We cannot seriously dispute the two-way connection between Osler's medical teaching-as-research on one hand, and the rise of several branches of medical science and clinical practice on both sides of the Atlantic, so in the history of science Professor Bliss has covered all the bases. The complaint remains that he has by no means covered the bases in the field of history on which he ought surely to depend still more-the history of the university.

$x+x$

We have, then, two biographies of learned and publicly effective academics, whose rhetoric and argument structures suggest they are at least partly consistent with the "new biography." Bliss does it better than Hill, but both are excellent in their ways, and both understand and accept the educational implication of new biography.

It matters not a bit if either writer has ever even heard of "new" biography. It does matter that this approach has informed their work, just because it has become so widespread a group of attitudes and practices among biographers, and not just literary biographers.

On the formal definition of education, the Acton biography is further from using the full fruit of recent research in histories of formal institutions, disciplines, and professions. Hill would have done better to introduce at least some of this material in accounting for the curiously fractured career of Lord Acton.

Bliss does pick that fruit, whether or not it turns up in his notes and bibliography. He would have gone further at key points in his discussion of Osler's American experience with the help of such university historians as Ringer, et al. But his book is no less a good book for all that.

Finally, on the question of mentorship, and an explicit treatment of this as a main departing point for biography, especially of men such as these. Here Hill's treatment of Acton is remarkably strong. He has the advantage of dealing with one dominant and lengthy apprenticeship (Acton-Döllinger), rather than hundreds (Sir William Osler and his hundreds of would-be apprenticeships in Canada, the USA, and England). The Osler biography could have been strengthened by closer attention to a small sample of case studies showing how mentorship and apprenticeship worked, evolved, and succeeded (or failed). 
Must biography be educational? Yes, and for many reasons, of which we are in presence of perhaps a dozen. Would biographers benefit from a closer study of at least some professional work in the field of educational history, particularly as it has grown up to be in the past quarter-century? Yes.

We have in Hill's and Acton's books not just first-rate biographies, but two first-rate works of history. I end with the suggestion that the historical biographer must surely accept the historian's mantle and obligation, that is, to accept new and evolving applications of historical method wherever appropriate. It can be done, and these authors have come close to doing so. Another generation of historians may now turn to take up these great methodological challenges. We would wish only that as they do, they aim to retain the standards of readability and accessibility that made Hill on Acton, and Bliss on Osler, into books general readers will buy. 